\title{
Opiniowanie sądowo-lekarskie a adwokatura w carskiej Rosji w XVIII stuleciu
}

\begin{abstract}
Streszczenie
W artykule ukazano początki powstania rosyjskiej adwokatury oraz jej wpływ na zwiększenie znaczenia medycyny sądowej w XVIII stuleciu. Poruszono problematykę udziału biegłych medyków w rozstrzyganiu kwestii związanych z oceną zdrowia i życia, a także rolę pełnomocników procesowych w postępowaniach dotyczących opiniowania sądowo-lekarskiego. Podkreślono doniosłe znaczenie Karty Wojskowej oraz Karty Morskiej Piotra I Wielkiego, a także działalności Ministerstwa Farmaceutycznego na terytorium państwa moskiewskiego.
\end{abstract}

Słowa kluczowe: adwokat, medycyna sądowa, Karta Wojskowa, Karta Morska, suplikant, autopsje.

\section{Początki opiniowania sądowo-lekarskiego w państwie rosyjskim}

Historia i rozwój opiniowania sądowo-lekarskiego były nierozerwalnie związane $\mathrm{z}$ kształtowaniem się i umacnianiem struktur państwowych oraz porządku prawnego, a także rozwojem medycyny. Na potrzeby postępowań sądowych oraz $\mathrm{w}$ innych przypadkach przewidzianych przepisami prawa władze państwowe zaczęly korzystać z wiedzy medycznej, nadając tego typu badaniom i ekspertyzom charakter czynności urzędowych. Nie może więc dziwić, że w Rosji szersze zainteresowanie państwa oraz prawa tymi zagadnieniami miało miejsce dopiero w XVIII stuleciu wraz z zapoczątkowanym przez Piotra I Wielkiego procesem budowy nowoczesnych struktur państwowych i instytucji prawnych. Po raz pierwszy 
prawnie usystematyzowano korzystanie z pomocy lekarzy i nauk przyrodniczo-medycznych na potrzeby sądowe ${ }^{1}$.

Pierwsze wzmianki o zainteresowaniu państwa urzędowym badaniem poszkodowanych pojawiły się jednak dużo wcześniej, bo w XI w. ${ }^{2}$ Wszelkich oględzin i obdukcji nie przeprowadzali wówczas medycy, lecz urzędnicy ${ }^{3}$ (najczęściej sędziowie $)^{4}$. W Ruskiej Prawdzie ${ }^{5}$ odnajdujemy ważne informacje odnośnie do kar za spowodowanie obrażeń ciała ${ }^{6}$, ustalonych w zależności od ich ciężkości ${ }^{7}$. Odnoszono się nie tylko do niewielkich obrażeń ciała, takich jak siniaki spowodowane użyciem tępej broni (np. kolby, pałki), ale i do rozległych ran krwawych będących wynikiem zastosowania ostrej broni (artykuły przewidywały karę za dźgnięcie

1 С.М. Громбах, Русская медицинская литература XVIII века, Изд-во Академии мед. наук СССР 1953, s. 64.

2 Niektórzy badacze sugerują, iż w okresie społeczeństwa słowiańskiego pojawiły się pierwsze odniesienia do wykorzystania wiadomości kryminalistycznych. Ich zdaniem traktaty Księcia Olega (911 r.) oraz Księcia Igora (945 r.) z Grekami, będące książęcym porozumieniem Rusi Kijowskiej z Bizancjum, jako pierwsze zawierały informacje o wzajemnej pomocy w przypadku zabójstwa oraz ciężkiego uszkodzenia ciała. Tekst tych umów niestety nie dotarł do naszych czasów, naukowcy zaś sugerują, iż nie był to akt prawny, lecz przyjęty zwyczaj. Zob. N. Kalachov, luridicheskiI viestnik 1863, nr 1, University of Chicago, s. 7-11; А. Решетун, Вскрытие покажет: Записки увлеченного судмедэксперта, Москва 2017, s. 4-31.

3 В.А. Клевно, Е.В. Кононов, История судебной медицины в России в X-начале XX века, Москва 2018, s. 47.

4 В. Акопов, Судебная медицина 3-е изд., пер. и доп. Учебник для бакалавров, Москва 2015, s. 30-31.

5 Ruska Prawda (Правда роусьска) była najstarszym zbiorem norm prawnych obowiązującym w Rusi Kijowskiej. Powstała w XI w., około 1016 r., pod rządami księcia Jarosława Mądrego i jego następców (pięć wieków po prawie salickim). Znane są dwie redakcje Ruskiej Prawdy: Krótka Prawda oraz Obszerna Prawda. Pierwsza zawierała przepisy z prawa karnego i procesu, druga uzupełniała przepisy statutem Włodzimierza Monomacha oraz modyfikacjami wnuków Jarosława. W XV stuleciu ukazała się Skrócona Prawda będąca wyciągiem Obszernej Prawdy, jednak nie odegrała ona istotnej roli w praktyce sądowej. Najważniejszą cechą Ruskiej Prawdy było to, że przypominała ona wczesne kodeksy europejskie - m.in. określała szczegółowo wysokość główszczyzny. Wiele jej postanowień przetrwało do czasu, gdy w Europie Zachodniej zlikwidowano niewolnictwo. Odkrywcą Ruskiej Prawdy w 1737 r. był Wasilij Tatiszczew.

6 Л.В. Черепнин, С.В. Юшков, Памятники русского права, t. 4, Москва 1957, s. 277-278.

7 В.И. Сергеевич, Лекции и исследования по древней истории русского права, СанктПетербург 1910, s. 426-427; I.B. Rakowiecki, Prawda ruska: czyli prawa wielkiego xiecia Jarowslawa Wladymirowicza... Rys historyczny zwyczaiów, obyczaiów, religiy, praw y jezyka dawnych slowiańskich y slowiańsko-ruskich narodow, t. 1, Warszawa 1820, s. 167. 
mieczem $\left.{ }^{8}\right)^{9}$. Kary były zróżnicowane w zależności od zranionej części ciała ${ }^{10}$. Ofiara mogła otrzymać rekompensatę, jednak w pierwszej kolejności uiszczano ją księciu (przestępstwa traktowano jako obrazę panującego). Co ciekawe, art. 67 Ruskiej Prawdy przewidywał wysoką karę za przymusowe pozbawienie brody i wąsów, które traktowano ówcześnie jako wyrządzenie dużej szkody cielesnej ${ }^{11}$. Większość przepisów Ruskiej Prawdy dotyczyła prawa karnego ${ }^{12}$, a przestępstwa znane temu zbiorowi prawa sprowadzały się przede wszystkim do naruszenia praw prywatnych ${ }^{13}$. Uszkodzenie ciała czy zabójstwo należały do najczęstszych przestępstw przeciwko prawom osób, jednak nie zauważono wówczas potrzeby korzystania z wiedzy lekarzy do rozwiązywania zagadnień kryminalistycznych.

Termin „medycyna sądowa” został użyty po raz pierwszy w 1690 r. przez światowej sławy niemieckiego lekarza, prekursora szkoły lipskiej - Johannesa Bohna ${ }^{14}$, który użył wówczas w swoim dziele sformułowania „medicinae forensis”15. Bohn jako pierwszy medyk w Europie określił szczegółowe zagadnienia związane z opiniowaniem sądowo-lekarskim i oddzielił je od reszty gałęzi lekarskich. Jego prace i badania naukowe zyskały ogromną sławę w wielu krajach Europy Zachodniej. Od tego momentu zaczęto interesować się udziałem lekarzy w rozwiązywaniu skomplikowanych przypadków prawnych. W przeciwieństwie do tych krajów, w Rosji przez całe wieki średnie do końca XVII stulecia nie można mówić o wyodrębnieniu tej nauki. Pojedyncze kryminalistyczne badania lekarskie zaczęto przeprowadzać

8 Л.В. Черепнин, С.В. Юшков, Памятники русского права: Памятники права киевского государства, Москва 1952, s. 89-151.

9 С.В. Ведров, О денежных пенях по Русской Правдь: сравнительно с законами Салических Франков, Москва 1877, s. 111; V. Sergeevich, Lektşii i izsliédovaníá́ po drevneй istorii russkage prava, Санкт-Петербург 1903, s. 414-416.

10 А.Н. Попов, Русская правда в отношении к уголовному праву, Москва 1841, s. 50-54.

11 M.N. Tokhomirov, A Manual for the Study of the Russian Truth. Publishing House of the Moscow University, Moscow 1953, s. 76-86; Свод законов Русская Правда Статья 67. О бороде - А если кто вырвет у кого клок бороды, и останется знак от этого, к тому же будут свидетели, то платить 12 гривен (12 гривен равнялось 6 коням, 15 коровам или 120 овцам. Вот сколько стоила борода свободного человека).

12 A.Z. Helcel, Rys postępów prawodawstwa karnego ze szczególnym uwzględnieniem na nowsze w tej mierze usiłowania, Kraków 1837, s. 49.

13 B. Sygit, Historia prawa kryminalnego, Toruń 2007, s. 351.

14 Esej Bohna wywołał wielką burzę. Medycyna sądowa zobowiązała wówczas lekarza do publicznego uzasadnienia i obrony swoich twierdzeń. Dodatkowo Bohn żądał zalegalizowania całej procedury sekcyjnej, a także otwarcia trzech jam ciała. Takie zmiany jako pierwsze przyjęło Księstwo Wirtembergii w 1686 r., dopiero później inne kraje Europy. Bez wątpienia Niemcy są uznawane za kolebkę medycyny sądowej, której historia w Rosji została zapoczątkowana wraz z panowaniem Piotra I Wielkiego.

15 J. Bohn, Specimen primum medicinae forensis, qvod superiorum præscitu \& assensu publico eruditorum examini submittit Johannes Bohn, ... respondente Joh. Gabriele Rudolff, Halo-Saxone. d. 5. Septembris 1690, Lipsiae 1690, s. 2-5. 
dopiero w II połowie XVII w. Najczęściej były to sporadyczne badania związane $\mathrm{z}$ uszkodzeniami mechanicznymi, ustalenia żywych narodzin niemowląt ${ }^{16}$ (próba hydrostatyczna płuc) ${ }^{17}$ czy podejrzenia o otrucie ${ }^{18}$.

\section{2. Аптекарский приказ jako centrum administracyjno-sądowe spraw medycznych państwa moskiewskiego}

Do tego czasu funkcjonowało założone przez Michaiła Federowicza w 1620 r. „Ministerstwo Farmaceutyczne"19 - Аптекарский приказ (Prikaz Farmaceutyczny) ${ }^{20}$, który pełnił zadania przede wszystkim z zakresu policji lekarskiej. Do jego kompetencji należało m.in. sprawowanie nadzoru nad aptekami i lekarzami, dostarczanie leków dla wojska, skup roślin leczniczych, prowadzenie scentralizowanych działań

16 Próba wodna płuc jest do dziś jedną z technik sekcyjnych. Polega na wrzuceniu narządów klatki piersiowej do naczynia wypełnionego wodą. Jeżeli dziecko urodziło się żywe, wówczas płuca będą unosity się na wodzie (dzięki znajdującym się w środku pęcherzykom powietrza). Wynik końcowy może być jednak dodatni lub ujemny - np. jeżeli noworodek zassał płyny płodowe lub rozpoczął się proces rozkładu (wówczas w płucach będą znajdowały się gazy wytworzone przez gnilne bakterie). Po raz pierwszy próba hydrostatyczna płuc została wykonana przez Bartholina z Kopenhagi w 1663 r., zaś dla celów sądowych wykonat ją Schreyer w 1682 r. Zob. L. Feigel, Podręcznik medycyny sądowej, na podstawie dziet E. Hofmanna, J. Maschki i własnego doświadczenia, Lwów 1883, s. 10.

17 А. Петрович Лей, Энциклопедический медицинский лексикон: Часть третья, Петербург 1844, s. 187-194.

18 Г.В. Архангельский, История неврологии от истоков до ХХ века, Москва 1965, s. 86; zob. В.И. Прозоровский, Судебная медицина, Москва 1968, s. 10; М. Мирский, Медицина России XVI-XIX веков, Москва 1996, s. 37-46.

19 П. Митрофанович Лукьянов, История химических промыслов и химической промышленности России до конца XIX века: Общие вопросы истории химической промышленности, Изд-во Академии наук СССР 1948, s. 22-26. Prikaz Farmaceutyczny zostat utworzony prawdopodobnie w połowie XVI w. za panowania Iwana Groźnego. W 1581 r. pojawiła się pierwsza apteka, z którą związane jest nazwisko angielskiego farmaceuty Jamesa Frencha. Początkowo apteka miała skromy zakres działania, gdyż przeznaczona była tylko dla rodziny królewskiej i dworu. Prikaz Farmaceutyczny był organem zarządzającym (nadzorczym) nad apteką. Kierownikami byli bojarzy odpowiedzialni również za pułkową i pałacową służbę medyczną. Z czasem w miastach rosyjskich zaczęły pojawiać się małe apteki wzorowane na Аптекарский приказ.

20 Obecnie słowo „prikaz” oznacza dosłownie „zamówienie”. W państwie moskiewskim od XV do XVIII stulecia prikazy były urzędami centralnymi, które kierowały poszczególnymi dziedzinami życia. Zob. И.И. Вернер, О времени и причинах образования московских приказов, Москва 1907-1908, s. 37-89. 
epidemiologicznych. Większość urzędników „Ministerstwa Farmaceutycznego” byli to cudzoziemcy, którzy zdobyli uznanie w ojczyźnie i listy polecające tamtejszych władców (dopiero w latach 80. XVIII stulecia pojawili się urzędnicy pełnoetatowi). Incydentalnie Prikaz uczestniczył również w czynnościach kryminalistycznych - prowadził działalność eksperckąa ${ }^{21}$ Wzmożona aktywność Anmекарскuŭ приказ nastąpiła w okresie panowania Piotra I Wielkiego, który zreformował jego zadania $^{22}$, wprowadzając m.in. nakaz badania przez lekarzy pacjentów, którzy doświadczyli szkód w wyniku niewłaściwej opieki medycznej ${ }^{23}$. Ówczesnym problemem rosyjskiej medycyny była jej niska skuteczność oraz brak wykwalifikowanych specjalistów - przez cały XVI i XVII w. wyrządziła ona więcej szkody niż pożytku. Lekarze popełniali wiele błędów medycznych, które przyczyniały się najczęściej do śmierci pacjentów lub doprowadzały do ich kalectwa. Dekret z 4 marca 1686 r. oraz dekret z 14 lutego 1700 r. $^{24}$ „Zdanie Bojarów” - Боярский приговор. О наказании не знающих медицинских наук, и по невежеству употребления медикаментов, причиняющих смерть больньм („W sprawie kary za nieświadome nauki medyczne i ignorancję w stosowaniu leków, które powodują śmierć pacjentów”) - przewidywały odpowiedzialność karną dla lekarzy za błędy lekarskie ${ }^{25}$. W tym okresie pojawiły się też pierwsze opinie dotyczące badania stanu zdrowia psychicznego. Najczęściej zajmowali się tym duchowni - mnisi, ponieważ zaburzenia psychiczne traktowano jako choroby natury duchowej. Chorych umieszczano w klasztorach zgodnie z Kartą Kościelną Włodzimierza z 996 r.

\section{Rola adwokatury rosyjskiej}

Opiniowanie sądowo-lekarskie w carskiej Rosji zyskało na popularności na początku XVIII stulecia w procesach karnych, gdy zaczęli pojawiać się lekarze jako profesjonalni znawcy medycyny ${ }^{26}$. Wykorzystanie wiedzy z zakresu nauk medycznych

21 И. Филиппович Крылов, Судебная экспертиза в уголовном прочессе, Ленинград 1963, s. 56.

22 В.Н. Васильевич, Аптекарский устав, извлеченный из Свода законов полных собраний законов, распубликованных циркуляров Министерства внутренних дел, постановлений Медицинского совета и разъясняемый историей законодательства, Санкт-Петербург 1880, s. 4-32.

23 А.А. Мохов, Основы медицинского права РФ, Издательство „Проспект” 2014, s. 239.

24 Nr 1171, [w:] Полное Собрание Законов Российской Империи: Собрание первое: С 1649 по 12 декабря 1825 года, t. II, Санкт-Петербург 1830, s. 747-748.

25 Nr 1756, [w:] Полное Собрание Законов Российской Империи: Собрание первое: С 1649 по 12 декабря 1825 года, t. IV, Санкт-Петербург 1830, s. 10-11.

26 В.Н. Козляков, Смута в России: XVII век, Москва 2007, s. 62-70. 
dla potrzeb sądowych przypadło na okres panowania cara Piotra I Wielkiego ${ }^{27}$. Wcześniej rosyjskie postępowanie karne miało zazwyczaj charakter kontradyktoryjny, zaś proces inkwizycyjny zwany rozyskiem lub syskiem występował sporadycznie $^{28}$. Reformy Piotra, dążącego do centralizacji wewnętrznej kraju, zaczęły się od wymiaru sprawiedliwości, który zdaniem władcy był zbyt otwarty i pobłażliwy. Od tego momentu stał się on brutalny i bezlitosny - wprowadzono najokrutniejsze i najbardziej pomysłowe tortury, karę śmierci zaś wykonywano publicznie ${ }^{29}$. Tortury wyeliminowano dopiero dekretem z 26 czerwca 1765 r. ${ }^{30}$ Dodatkowo imperator wprowadził instancyjność postępowania w sprawach cywilnych i karnych, a także powołał senat, od którego wyroków nie przysługiwało odwołanie. W $1715 \mathrm{r}$. po raz pierwszy w przepisach wojskowych został użyty termin адвокат (obrońca, prawnik). Pojęcia „obrońca” i „prawnik” pojawiły się wówczas w odniesieniu do przedstawicieli stron ${ }^{31}$ i były używane naprzemiennie. W XV w. pełnomocnicy procesowi - „wspólnicy” i „najemcy” (партнеров и арендаторов) pojawili się po raz pierwszy w księgach nowogrodzkich oraz kartach sądowych Pskowa ${ }^{32}$, jednak z ich usług mogła korzystać tylko określona grupa osób (kobiety, dzieci, osoby starsze i ułomne, duchowni - mnisi, a także osoby głuche lub nieme) $)^{33}$. Zgodnie z ułożeniem soborowym cara Aleksieja Michajłowicza z 1649 r. (Уложение Алексея Михайловича) w przepisie $108^{34}$ zezwalano powodowi oraz oskarżonemu w przypadku choroby na ustanowienie pełnomocnika ${ }^{35}{ }^{36}$. W XVIII stuleciu

27 E.M. Becker, Medicine, Law, and the State in Imperial Russia, New York 2011, s. 1.

28 D.A. Sołodov, Reformy procesu karnego w Rosji: zarys historyczno-prawny, Łomża 2015, s. 30.

29 Н.Ш. Коллманн, Преступление и наказание в России раннего Нового времени, Москва 2017, s. 34.

30 Полное собрание законов Российской Империи, t. XVII, nr 12324, Петербург 1830, s. 20.

31 Ю.И. Стецовский, Становление адвокатуры в России, Москва 2010, s. 101.

32 В. Иванович Смолярчук, Адвокат Феодор Плевако: Очерк о жизни и судебной деятельности адвоката Ф.Н. Плевако, Юж.-Урал. кн. Изд-во 1989, s. 47.

33 М.Н. Тихомиров, Пособие для изучения Русской Правды, Издательство Московского Университета, Москва 1953, s. 11-16.

34 М.Н.Тихомиров, П.П. Епифанов, Соборное уложение 1649 года, Изд-во МГУ, Москва 1961, s. 112-113.

35 Соборное уложение 1649 года, Москва: Печатный двор, 29 января 1649, s. 143-145.

36 „А которые исцы и ответчики, не ходя в суд; учнут приносити отсрочные челобитные за своими руками, а в челобитных у них будет написано, что им межь себя сыскиватися, а будет не сыщутся, и им обема стати в приказе к суду на срок, как они межь себя договорятся, а будет кто из них на тот срок не станет, и тому тем сроком быти виновату, да подав такую челобитную, кто из них один на срок в приказе станет и челобитье свое запишет, а другой на тот срок не станет, и того тем сроком, по их полюбовному челобитью, обвинити, опричь крепостных дел. А будет истец или ответчик до того отсрочного сроку занеможет, и за болезнию ему в приказ итти будет никоторыми делы немочно, и ему в свое место прислати на срок искати, или отвечати кому верит. А будет на тот полюбовной срок кто в свое место искати и отвечати никого не пришлет, и его тем по тому же обвинити, а будет кто об нем учнет бити челом, что он конечно болен, 
działalność prawników stała się niezwykle biurokratyczna i zakulisowa. Piotr I Wielki udawał, że nie dostrzega znaczenia tego zawodu, chcąc przede wszystkim ograniczyć ich metody „prowadzenia interesów”, i wypowiadał się niepochlebnie w ten sposób: „Gdy adwokaci (prawnicy) są wykorzystywani do prowadzenia spraw, wówczas są bardziej kłopotliwi dla sędziego z powodu ich obscenicznych pomysłów, zaś sprawy najważniejsze prowadzone $\mathrm{z}$ ich udziałem przeciągają się w nieskończoność" ${ }^{37}$. Warto dodać, iż jeden z rozdziałów Karty Wojskowej z 1716 r. nosił nazwę „O prawnikach i pełnomocnikach”38. Fakt ten tłumaczy, iż krajowe orzecznictwo Piotra I Wielkiego dało wielki impuls do rozwoju świeckiej edukacji prawnej, zaś postępowania sądowe nabrały charakteru sądownictw polowych ${ }^{39}$. Zgodnie z Kartą adwokaci pojawiali się jako zastępcy podczas procesu w przypadku niedyspozycji suplikanta i pozwanego. Dopiero dekret carycy Katarzyny II z 1775 r. dotyczący prowincji ustanowił nowe zadania adwokatów, którzy pełnili wówczas funkcję asystentów prokuratorów. Nie ma jednak żadnych informacji dotyczących kwalifikacji do pełnienia tego zawodu. Dla opiniowania sądowo-lekarskiego rozwój adwokatury w Rosji mógł odgrywać istotną rolę, szczególnie w sprawach o unieważnienie małżeństwa z powodu niemocy płciowej, dochodzenie ojcostwa, dochodzenie ciąży i porodu. Niestety, dopiero w XIX stuleciu, gdy nastąpiła reforma sądownictwa, prawnicy z wielkim trudem zajęli właściwe sobie miejsce w rosyjskim społeczeństwie ${ }^{40}$, co również wpłynęło na dalszy rozwój medycyny sądowej, szczególnie w procesach cywilnych. W latach 60. XIX w. powstała m.in. instytucja przysięgłych adwokatów ${ }^{41}$.

а к суду ему в свое место прислати неково, что он безсемейной и безлюдной человек, и того болново послати осмотрити подьячево доброво. Да будет он по осмотру конечно болен, и к суду ему быти немощно, и в свое место послати ему некого, и его тем полюбовным сроком без суда не винити, и дати ему сроку до тех мест, как он обможется".

37 „Когда адвокаты у сих дел употребляются, оные своими непотребными пространными приводами судью более утруждают, и оное дело толь паче к вящему пространству, нежели к скорому приводят окончанию”. Do XV w. w Rosji nie istniat termin „obrońca”. W XVIII stuleciu zostały określone wymagania dotyczące adwokatów (prawników). Ludzie ci mieli pochodzić ze szlachetnej rodziny, posiadać czyste sumienie i uczyć się od doświadczonych przedstawicieli zawodu. Nie zapewniono żadnej innej edukacji. Później „obrońcy” i „prawnicy” zaczęli nazywać się adwokatami, zaś w XIX w. powstała pierwsza instytucja adwokacka. Zob. Н.К. Панько, Присяжные поверенные и адвокаты:история развития, сравнительный анализ их правового статуса и полномочий по уставу уголовного судопроизводства 1864 года и законодательству российской федераци, [w:] Судебная власть и уголовный процесс, nr 3, Роскомнадзора Москва 2014, s. 243-251.

38 Kodeks Wojskowy Piotra I z 1716 roku, opr. P. Krokosz, K. Łopatecki, Kraków-Oświęcim 2016, s. 298.

39 И.Н. Сухих, Д.С. Лихачева, Петр Великий в русской литературе: воспоминания, оценки, образ, Санкт-Петербург 2009, s. 220.

40 Е. Князев, История России. Вторая половина XIX - начало XX века 2-е изд., испр. и доп. Учебник для академического бакалавриата, Москва 2019, s. 40-61.

41 А.В. Гриненко, Ю.А. Костанов, С.А. Невский, В.Д. Потапов, Об адвокатской деятельности и адвокатуре в Российской Федерации. Научно-практический комментарий. учебное пособие, Москва 2019, s. 1-5. 


\section{Karta Wojskowa i Karta Morska Piotra I Wielkiego}

Z przepisów prawnych znajdujących się w kartach wojskowych Piotra I wynika, że korzystał on z pomocy medyków dla rozwiązania kwestii sądowo-lekarskich. $\mathrm{Za}$ oficjalną datę pierwszego sądowego badania lekarskiego uznaje się $10 \mathrm{kwiet}$ nia 1716 r. ${ }^{42}$ Tego dnia w Gdańsku Piotr I Wielki zatwierdził Kartę Wojskowąa która była jednym z najważniejszych dokumentów prawnych i politycznych w historii. Głównym celem Piotra I Wielkiego było unowocześnienie państwa, a także przeobrażenie go w największe na świecie mocarstwo. Oświeceniowe reformy cara rozpoczęly się zatem od zmilitaryzowania swojego kraju. Efektem tego było powoływanie lekarzy do służby, zadania opieki zdrowotnej zostały zaś ściśle podporządkowane interesom wojskowym. Artykuł 154 Karty Wojskowej w rozdziale $\mathrm{XIX}^{44}$ nakazywał przeprowadzanie sekcji zwłok w przypadku śmierci gwałtownej, a także stwierdzenie przyczyny śmierci denata - „Przedtoż bardzo jest rzecz potrzebna, aby skoro ten, którego zbito, pchnięto lub cięto, umrze, kilku feltszerow ordynowano, aby ciało umarłego otworzyli i pilnie egzaminowali, co była za przyczyna jego śmierci. Swoje zdanie powinni poprzeć przysięgą i złożyć na piśmie w sądzie" ${ }^{45}$. Artykuł 154 początkowo został wprowadzony dla wojska i marynarki wojennej, następnie rozszerzono jego obowiązywanie w 56 największych miastach rosyjskich. Opracowano dokładne wyliczenie najpopularniejszych obrażeń ciała, które skutkowały śmiercią lub były uleczalne, a także opisano ich cechy. Katalog ten przewidywał m.in. ciężkie i lekkie urazy głowy (mózgu), rany w płucach, rany serca, krtani, błony, jamy brzusznej (żołądka, jelit, wątroby, śledziony), rany i obrażenia spowodowane przez zwierzęta lub trujące rzeczy ${ }^{46}$. Finalnie orzeczenie o przyczynie śmierci i okolicznościach przedstawiał sąd, nie lekarz.

Karta Wojskowa z pewnością miała ogromne znaczenie dla rozwoju nauk lekarskich, szczególnie medycyny sądowej, a także organizacji całej służby kryminalistycznej Rosji. Piotr I nie uważał jej za wąską regulację prawną dla wojska, lecz

42 В. Хохлов, Судебная медицина. Руководство в 3 m. Том 1 4-е изд., пер. и доп. Практическое пособие, Москва 2019, s. 67.

43 Устав воинский, [w:] Полное собрание законов Российской империи, с 1649 года. -Типография II отделения Собственной Его Императорского Величества канцелярии, t. V, Санкт-Петербург 1830, s. 203-204.

44 „Надлежит подлинно ведать, что смерть всеконечно и от бития приключилась... Того ради зело потребно есть, чтобы, коль скоро кто умрет, который в драке был и бит, поколот или порублен будет, лекарей определить, которые бы тело мертвое взрезали и подлинно разыскали, что какая причина к смерти его была и в том иметь свидетельство в суде на письме подать и оное присягой своей утвердить".

45 Kodeks Wojskowy Piotra I..., s. 272.

46 Tamże, s. 274. Устав воинский, [w:] Полное собрание законов Российской империи, с 1649 года. Типография II отделения Собственной Его Императорского Величества канцелярии, t. V (1713-1719), Санкт-Петербург 1830, s. 364-366. 
za kodeks mający centralne i szerokie zastosowanie dla całego państwa i prawa. W przedmowie do Karty z 1716 r. napisał, iż „stosuje się ją do wszystkich władców ziemskich" ${ }^{47}$. W tym samym roku przekształcono Zakon Farmaceutyczny i utworzono w Petersburgu Kancelarię Medyczną, która była najwyższym organem lekarskim w carskiej Rosji ${ }^{48}$. W 1721 r. car Piotr I wydał dekret powołujący do życia Biuro Medyczne - Медицинская коллегія ${ }^{49}$. Dekretem z 12 listopada 1763 r. Katarzyna II zmieniła jego nazwę na Collegium Medyczne ${ }^{50}$. Od 1716 r. instytucja ta, chociaż wielokrotnie zmieniała nazwy, była przez cały XVIII w. centralną instytucją państwową odpowiedzialną za sprawy medyczne z zakresu policji lekarskiej oraz zagadnień kryminalistyczno-medycznych. W 1718 r. z inicjatywy Piotra I w Petersburgu rozpoczęto po raz pierwszy masową produkcję narzędzi chirurgicznych, w tym narzędzi urologicznych ${ }^{51}$. Imperator był żywo zainteresowany zagadnieniami chirurgicznymi, do tego stopnia, że sam wykonał kilka prostych operacji ${ }^{52}$, niekiedy asystował również przy zabiegach chirurgicznych.

Kolejnym aktem prawnym, który regulował przepisy dotyczące opiniowania sądowo-lekarskiego w carskiej Rosji, była ustawa morska z 13 kwietnia 1720 r. ${ }^{53}$ Ustawa morska, zwana również Kartą Morską, była pierwszym (i najważniejszym) aktem kodyfikującym niektóre prawne aspekty życia morskiego w carskiej Rosji. Składała się ona z szeregu przepisów określających taktykę eskadry, zasady postępowania na statku, a także sądowo-dyscyplinarnych zaleceń, które do 1797 r. były

47 Устав воинский, [w:] Полное собрание законов Российской империи, с 1649 года-Типография II отделения Собственной Его Императорского Величества канцеляриит, t. V (1713-1719), Санкт-Петербург 1830, s. 203-453.

48 И. Ионасович Левинштейн, История фармации и организация фрармацевтического дела, Москва-Ленинград 1939, s. 96.

49 К.А. Неволин, Изсльдованія о различных предметах законовьдьнія, Санкт-Петербург 1859, s. 232-233.

50 И. Кузьмич Кондратьев, Сьдая старіна Москвы: историческій обзор и полный указатель ея достопамятностей: соборов, монастырей, церквей, стьн, дворцов, памятников, общественных зданій, мостов, площадей, улии, слобод, урочищ, кладбищ, и проч. и проч.: с подробным историческим описаніем основанія Москвы и очерком ея замьчательных окрестностей, Москва 1893, s. 1; В. Верекундов, Историческій очерк Кафедры диагностики и общей терапіи в Императорской военно-медицинской академіи (Кафедры общей патологіи, общей терапіи и врачебной діагностики в Императорской медико-хирургической академіи): матеріалы для исторіи медицины в Россіи, Санкт-Петербург 1898, s. 6.

51 П. Гнилорыбов, В. Зырянов, М. Томчин, Россия в эпоху Петра Великого. Путеводитель путешественника во времени, Москва 2017, s. 123.

52 Ч.М. Таксами, Т. Константиновна Шафрановская, Е. Владимировна Иванова, Приглашаем в Кунсткамеру, Санкт-Петербург 2001, s. 15.

53 Книга Устав морской о всем, что касается доброму управлению, в бытности фрлота на море, Напечатася повелением царскаго величества, 6-м тиснением, При Императорской Академии наук, Санкт-Петербург 1780, s. 1-3. 
głównymi przepisami zarządzającymi marynarką wojenną Imperium ${ }^{54}$. Pojawiły się wśród nich przepisy dotyczące zagadnień z zakresu medycyny sądowej. W przepisie 108 ustawy morskiej ${ }^{55}$ znajdujemy informacje dotyczące śmierci gwałtownej w wyniku choroby lub pobicia wraz z obowiązkowym przeprowadzeniem oględzin zwłok przez lekarza ${ }^{56}$. Na mocy tego paragrafu lekarz był zobowiązany złożyć oświadczenie pod przysięgą przed sądem z przeprowadzonych badań. Przepis 114 ustawy morskiej ${ }^{57}$ nakazywał wykonanie sekcji zwłok przez lekarza, a także oględziny ran powstałych na polu bitwy, w wyniku tortur lub tych, które skutkowały śmiercią, wraz z określeniem ich właściwości. Przepis ten przewidywał również badanie symulacji choroby (w celu uniknięcia obowiązkowej służby wojskowej). Karta Morska nakazywała ukaranie lekarza, który dopuścił się zaniedbania swoich obowiązków względem chorych, kierował się lenistwem lub pogardą (przepis 9) ${ }^{58}$.

\section{Petersburskie autopsje w I połowie XVIII w.}

Kodeks Wojskowy oraz Karta Morska Piotra I były impulsem do dalszej systematyzacji kwestii z zakresu opiniowania sądowo-lekarskiego również w przypadku procedury cywilnej. Z inicjatywy Piotra I Wielkiego na synodzie w 1723 r. wydano

54 Ф. Веселаго, Краткие сведения о русских морских сражениях за два столетия с 1656 по 1856 год, Санкт-Петербург 1871, s. 3-64.

55 „Кто кого убиет так, что он не тотчас, но по некотором времени умрет, то надлежит, о том освидетельствовать, что он от тех ли побоев умре, или иная какая болезнь приключилась, и для того тотчас по смерти его докторам изрезать то мертвое тело и осмотреть, от чего ему смерть приключилась, и о том свидетельство к суду подать на письме, подтвержденное присягою".

56 Кніга устав морской: о всем что касаеця доброму управленію в бытности фллота на морь, Санкт-Петербург 1765, s. 147.

57 „Параграф 114. Ежели учинится драка, что многие одного станут бить и в одной явится мертвой от какой раны или смертного удара или много бою, то те, кто в том были разыскать с умыслу ли то делали. А о ранах смертных, кто учинил. В чем ежели не сыщется расспросом и пытать. А буде мертвый явится без всяких явных знаков, то его велеть доктору анатомировать, не явится ли внутри ль от того бою чего. И буде явится, то такоже разыскать. А буде не явится, то такоже разыскать. А буде не явится то оное причесть случаю и наказать только за драку" - Кніга устав морской: о всем что касаеця доброму управленію в бытности фллота на морь, Санкт-Петербург 1765, s. 149.

58 „Параграф 9. Ежели лекарь своим небрежением и явным призорством к больным поступит, от чего им бедство случится, то оной яко злотворец наказан будет, яко бы своими руками его убил, или какой уд отсек, буде же леностью учинит, то знатным вычетом наказан будет по важности и вине осмотря в суде". Книга Устав морской о всем, что касается доброму управлению, в бытности флота на море, При Императорской Академии наук, Санкт-Петербург 1778, s. 32-34. 
dekret, który nakazywał zbadanie małżonków przez lekarza przed orzeczeniem rozwodu ${ }^{59}$. Z czasem zapraszano również medyków do badania innych przypadków, najczęściej w sprawach kryminalnych. Zajmowali się oni m.in. badaniem toksycznych substancji chemicznych, które skutkowały śmiercią, nielegalnym leczeniem czy okaleczeniami. W 1746 r. ukazała się instrukcja sekcyjna Lestoka, starszego administratora medycznego (archiatry) ${ }^{60}$, dotycząca autopsji kryminalistycznych. Wyraźnie zaznaczono, iż młodzi chirurdzy przy wykonywaniu autopsji w salach szpitalnych powinni wykonywać je, ucząc się przy tym sądowego poszukiwania przyczyny śmierci ${ }^{61}$, zwłoki zaś wysyłano do teatrów anatomicznych w każdym mieście ${ }^{62}$. Z dekretu senackiego (1737) wynika, że już w pierwszej połowie XVIII w. policja i instytucje sądowe utrzymywały specjalnych lekarzy, którzy pełnili czynności medyków sądowych ${ }^{63}$. Zakładanie szpitali było nieodzownym elementem rozwoju opieki medycznej, a także edukacji kryminalistyczno-lekarskiej. Zdaniem Johanna Bernarda von Fishera, dyrektora generalnego gabinetu lekarskiego w Petersburgu, autopsje miały olbrzymie znaczenie dla rozwoju i dalszego szkolenia lekarzy. Jego raporty mówią, że szczególnie w okresie zimowym często wysyłano zwłoki z policji lub zwłoki ludzi znalezionych do sekcjonowania ${ }^{64}$. W latach 30. i 40. XVIII w. dynamicznie zaczęło rozwijać się również petersburskie położnictwo, chirurgia i anatomia, będące najważniejszymi dyscyplinami dla dalszych badań naukowych nad zwłokami. Pomiędzy zadaniami kryminalistycznymi a medycznymi zaczęli pośredniczyć przedstawiciele policji lekarskiej. Byli to fizycy związani z policją, a także sądami okręgowymi. Dekret z 1746 r. był oczywiście zasługą Piotra I, który był nie tylko wybitnym politykiem, ale i oczytanym władcą, świadomym potrzeby anatomicznego oświecenia. Co ciekawe, już w 1699 r. po raz pierwszy zorganizował on w Moskwie kurs anatomiczny dla bojarów z demonstracjami na zwłokach ${ }^{65}$.

59 К.А. Пашков, П.О. Ромодановский, Г.А. Пашинян, Судебная стоматология - страницы истории, Москва 2009, s. 35.

60 Archiatrą nazywano fizyka, który pełnił swoje obowiązki również na dworze i wyróżniał się wysoką rangą społeczną.

61 Я.А. Чистович, История медицинских школ в России, Санкт-Петербург 1883, s. 257.

62 Д. Смирнов, Нижегородская старина: Нижегородские были, Нижний Новгород 1995, s. 260.

63 Полное собрание законов Российской империи, с 1649 года, Санкт-Петербург, Типография II отделения Собственной Его Императорского Величества канцелярии, 1830, t. X, $\mathrm{nr} 7245$, s. $136-138$.

64 J.B. von Fischer, Liefländisches Landwirthschaftsbuch: auf die Erdgegend von Lief- Est- und Curland Eingerichtet. Die Vortheile des Feldbaus, der Viehzucht und Haushaltung. Die Ursachen und Mittel der Viehseuche. Die cur verschiedener Bauerkrankheiten und Sonderlich der Pest, Lehrreich, Gründlilch und nach ihren Ursachen Vorgetragen Werden. worinne I, II, III, Magdeburgischen 1753, s. 39-388.

65 J.G. Koritké, Archives d'anatomie, d'histologie et d'embryologie normales et experimentales, t. 60, Leningradskoe 1971, s. 102. 


\section{Opiniowanie sądowo-lekarskie w okresie panowania Katarzyny II}

Reformy Katarzyny II, następczyni Piotra I Wielkiego, również skupiały się wokół zmiany sądownictwa, a także dalszego rozwoju medycyny sądowej. Były one znacznie bardziej przemyślane niż za panowania poprzednika ${ }^{66}$. Katarzyna $\mathrm{II}^{67}$ dążyła do oddzielenia procesu karnego od cywilnego, a także jednolitej formy postępowania we wszystkich sądach, tworząc tzw. sądy równych ${ }^{68}$. Środek dowodowy w postaci zeznań biegłego lekarza pojawiał się już w II połowie XVIII stulecia. Zgodnie z ukazem senackim z 20 kwietnia 1762 r. osoby chore psychicznie umieszczano w specjalnych domach dla obłąkanych, ich majątki zaś zwracano pod nadzór spadkobierców ${ }^{69}$. Cesarz Piotr III i Katarzyna II wzorowali się na europejskim modelu - dolgauz ${ }^{70}$, a zgodnie z dekretem z $1772 \mathrm{r}$. każdy okręg musiał zbudować taki szpital psychiatryczny dla obłąkanych ${ }^{71}$. Niestety były one podobne do więzień, pacjentów przetrzymywano zaś w niehigienicznych warunkach, a także

66 А.Б. Каменский, Om Петра I до Павла I. Реформы в России XVIII века. Опыт целостного анализа, Российский государственный гуманитарный университет, Москва 2001, s. 332.

67 Podobnie jak Piotr I caryca odniosła się do prawników tymi słowami: „Prawnicy i prokuratorzy nie ustanawiają ze mną prawa i nie będą stanowić prawa podczas mojego życia, a po mnie będą przestrzegać moich zasad” („Адвокаты и прокуроры у меня не законодательствуют и законодательствовать не будут, пока я жива, а после меня будут следовать моим началам").

68 B. Crosby, Authentic Memoirs of the Life and Reign of Catherine II. Empress of all the Russias, collected from authentic MS'S, translations, \&c. of the King of Sweden, Right Hon. Lord Mountmorres, Lord Malmesbury, M. De Volney, and other indisputable authorities, London 1797, s. 72-79; Т.Ю. Амплеева, История уголовного судопроизводства России, Москва 2009, s. 50.

69 П.П. Кащенко, Ближайшие задачи в деле попечения о душевнобольных, Современная психиатрия 1911, s. 485-513.

70 А.А. Нечаев, Очерки по истории Обуховской больницы. Л., 1952, s. 3-618; А.Б. Белевитин, В.И. Немченко, Обуховская больница, Санкт-Петербург 2003.

71 Dekret z 1762 r. był pierwszym dokumentem, który regulował sytuację osób z zaburzeniami psychicznymi. Utworzono specjalną komisję pod przewodnictwem Mullera, który stworzył projekt szpitali psychiatrycznych dolgauzv (toll - szalony i haus - dom). W tym roku w Moskwie powstał pierwszy dom psychiatryczny, co stanowiło również początek polityki państwowej dobroczynności. Projekt ten jedynie szlachtę traktował jako klasę uprzywilejowaną. Główną przyczyną działań w kwestii rozwoju psychiatrii była wysoka liczba przestępstw i niebezpiecznych czynów, które zmusiły władze administracji do zastosowania środków w celu ochrony porządku publicznego. Dekret Katarzyny II z 1767 r. nakazywał mieszkańcom Petersburga informować policję o osobach psychicznie chorych („szaleńcach”) znajdujących się w ich domach w celu ich rejestracji pod groźbą kary grzywny. Pierwszy taki dom powstał w Nowogrodzie w 1776 r. Psychiatria sądowo-lekarska narodziła się dopiero w XIX stuleciu. W 1834 r. pojawił się podręcznik Petera Butkowskiego Choroba psychiczna, w którym autor 
często poddawano torturom ${ }^{72}$. Wielu badaczy uznaje ten okres za solidny fundament dla psychiatrii sądowo-lekarskiej, jednak dopiero kolejne stulecie rozwinęło tę gałąź medycyny sądowej. Po raz pierwszy na mocy dekretu cesarza Aleksandra z 1801 r. „O niepowodzeniu sądowym ludziom w ich umysłach i którzy popełnili morderstwo w tym stanie" uregulowano problem udziału lekarza psychiatry w postępowaniu karnym, a także wprowadzono dekret o zniesieniu tortur ${ }^{73}$.

W 1775 r. Katarzyna II wprowadziła podział administracyjny, który przetrwał do 1917 r. $^{74}$ - zwiększyła liczbę guberni, podzieliła je na powiaty, a także połączyła w większe okręgi. Udoskonalając system zarządzania i zasadę podziału władzy, Katarzyna oddzieliła sądownictwo od władzy wykonawczej. Każde miasto było zobowiązane do posiadania lekarza, podobnie każdy powiat posiadał medyka ${ }^{75}$, który zajmował się zagadnieniami kryminalistyczno-medycznymi, m.in. wykonywał sekcje zwłok noworodków, autopsje w przypadkach śmierci gwałtownej, badał stan psychiczny pokrzywdzonego lub oskarżonego, prowadził badania z zakresu chemii i toksykologii sądowo-lekarskiej, a także określał przydatność do służby wojskowej ${ }^{76}$. Pierwszą instytucją w historii Rosji, w której zaczęły kształtować się kryminalistyczne badania lekarskie, była Akademia Nauk w Petersburgu ${ }^{77}$. Początkowo działalność kryminalistyczna Akademii ograniczała się do kwestii medycznych, ale potrzeba analizy dokumentów i substancji doprowadziła do rozpoczęcia kryminalistycznych badań chemicznych ${ }^{78}$. Znaczna część naukowców zaczęła przyjmować wnioski o badanie produktów w celu ustalenia składu ilościowego złota i srebra. Duża liczba badań została przeprowadzona osobiście przez M.W. Łomonosowa (szczególnie w zakresie chemii) ${ }^{79}$. Zgodnie z ukazem senackim z 1797 r. wyznaczano lekarzy w większych miastach

opisał ćwiczenia fizyczne potrzebne w leczeniu osób upośledzonych umysłowo, zaś w 1857 r. Iwan Baliński jako pierwszy zaczął prowadzić wykłady z zakresu psychiatrii.

72 Н.Н. Баженов, История Московского Доллгауза, ныне Московской городской Преображенской больницы для душевнобольных, Москва 1909, s. 9-23; В. Сербский, Приговор. Об экспертизе душевнобольных и преступников, Москва 2019, s. 18.

73 Zob. Полное собрание законов Российской Империи, t. XV, Санкт-Петербург 1832.

74 А. Николаевич Бубенников, История земли Можайской Руси Святой: 512 г. до н.э. 1812 г, Можайск, Парад 2003, s. 334.

75 Полное собрание законов Российской империи, с 1649 года, t. XX, Nr 14392, Санкт-Петербург 1830, s. 434.

76 В. Акопов, Судебная медицина 3-е изд., пер. и доп. Учебник для бакалавров, Москва 2015, s. 32.

77 А.В. Дулов, Судебная медицина и Петербургская академия наук, Судебно-медицинская экспертиза, 1962, nr 2, s. 42-45.

78 А.В. Доливо-Добровольский, ․О. Харламова, Санкт-Петербург. Хроника трех столетий, Петербург 2003, s. 142-186.

79 Н. Михайлович Раскин, Химическая лаборатория М.Б. Ломоносова: химия в Петербургской Академии наук во 2-й половине XVIII в, зд-во Академии наук СССР [Ленинградское отд-ние] 1962, s. 299-316. 
rosyjskich, którzy wykonywali czynności lekarskie na polecenie sądów ${ }^{80}$. Rok później medycyna sądowa jako przedmiot akademicki pojawiła się na Akademii Moskiewskiej i Petersburskiej.

\section{Konkluzje}

Opiniowanie sądowo-lekarskie w carskiej Rosji rozwinęło się w XVIII stuleciu. Duży wpływ na kształtowanie się medycyny sądowej w późniejszych wiekach odegrało prawodawstwo Piotra I Wielkiego (Karta Morska, Karta Wojskowa), a także początki rozwoju psychiatrii sądowo-lekarskiej w okresie panowania Katarzyny II. W przypadku podejrzenia gwałtownej śmierci do połowy XVIII stulecia lekarze pojawiali się na miejscu zdarzenia jeszcze sporadycznie, jednak w II połowie tego wieku wzywanie ich stało się obowiązkowe. Dane z badania lekarskiego dołączano do protokołu policyjnego. Badania osób żywych od połowy XVIII w. przeprowadzali już tylko lekarze. W tym okresie również wiele organów administracyjno-medycznych zajmowało się badaniami z zakresu medycyny sądowej (m.in. słynny Аптекарский приказ, później przemianowany na Medical College). Niestety większość lekarzy była przez całe XVIII stulecie powołana przede wszystkim do pełnienia służby wojskowej, dlatego też przedstawione regulacje były niedopracowane i niejednolite. Nie bez znaczenia był również fakt, iż liczba prawników w carskiej Rosji była znikoma, co negatywnie wpływało na rozwój opiniowania sądowo-lekarskiego. Adwokaci rosyjscy dopiero pod koniec XVIII stulecia i jako asystenci prokuratorów mogli uczestniczyć w postępowaniu sądowym z zakresu nauk kryminalistyczno-medycznych. Brak wykwalifikowanych pełnomocników procesowych, a także ówczesny stan wiedzy sądowo-lekarskiej nie pozwalał na uzyskanie większej liczby informacji dowodowych. W starych dokumentach sądowych nie znajdziemy np. opisu śladów użycia broni palnej czy odcisków palców ${ }^{81}$. Niezależna adwokatura pojawiła się w Rosji w 1864 r. w wyniku reformy sądownictwa, co radykalnie zmieniło rosyjski wymiar sprawiedliwości. Co ciekawe - teraźniejsza reforma powtarza wiele założeń cara Aleksandra II z XIX stulecia. Nauczanie medycyny sądowej rozpoczęło się w latach 90. XVIII w. na Uniwersytecie Moskiewskim $^{82}$, a profesorami na rosyjskich uniwersytetach byli również

80 Полное собрание законов Российской империи, с 1649 года. Т. 24. С 6 ноября 1796 по 1798, Санкт-Петербург 1830, s. 396.

81 D. Sołodov, Reformy procesu..., s. 28.

82 А. Юрьевич Андреев, Московский университет в общественной и культурной жизни России начала XIX века, Москва 2000, s. 181-182. 
Polacy $^{83}$. Ukaz senacki z 1797 r. przydzielał obowiązki sądowe lekarzom w większych miastach rosyjskich ${ }^{84}$ takich jak Psków, Nowogród czy Jarosław. Świadczy to o tym, że rosyjska medycyna sądowa została wyodrębniona i oddzielona spośród wielu gałęzi nauk lekarskich pod koniec XVIII w. Niestety dopiero w XIX stuleciu lekarze sądowi otrzymali pozycję najważniejszych ekspertów w procesach dotyczących skomplikowanych kwestii sądowo-lekarskich. Pierwszym istotnym krokiem ku tym zmianom było powołanie Rady Lekarskiej w 1803 r. pod zarządem Państwowej Komisji Lekarskiej, co sprawiło, że rozwój medycyny sądowej stał się dużo bardziej precyzyjny i nowoczesny niż w poprzednim stuleciu.

\section{Bibliografia}

\section{Źródła archiwalne}

Bohn J., Specimen primum medicinae forensis, qvod superiorum proscitu \& assensu publico eruditorum examini submittit Johannes Bohn, ... respondente Joh. Gabriele Rudolff, Halo-Saxone. d. 5. Septembris 1690, Banckmanniano, Lipsiae 1690, s. 2-5.

von Fischer J.B., Liefländisches Landwirthschaftsbuch: auf die Erdgegend von Lief- Est- und Curland Eingerichtet. Die Vortheile des Feldbaus, der Viehzucht und Haushaltung. Die Ursachen und Mittel der Viehseuche. Die cur verschiedener Bauerkrankheiten und Sonderlich der Pest, Lehrreich, Gründlilch und nach ihren Ursachen Vorgetragen Werden, worinne, I-III, gedruckt ben Johann Suffimus Gebauern Magdeburgischen 1753, s. $39-388$.

Kodeks Wojskowy Piotra I z 1716 roku, opr. P. Krokosz, K. Łopatecki, Wydawnictwo Napoleon, Kraków-Oświęcim 2016.

Васильевич В.Н., Аптекарский устав, извлеченный из Свода законов полных собраний законов, распубликованных ииркуляров Министерства внутренних дел, постановлений Медицинского совета и разбясняемьй историей законодательства, Тип. М-ва вн. Дел, Санкт-Петербург 1880, s. 4-32.

Книга Устав морской о всем, что касается доброму управлению, в бытности флота на море, Напечатася повелением царскаго величества, 6-м тиснением, При Императорской Академии наук, Санкт-Петербург 1780, s. 1-3.

Книга Устав морской о всем, что касается доброму управлению, в бытности флота на море, При Императорской Академии наук, Санкт-Петербург 1778, s. 32-34.

83 F. Hechel, Historyczno-krytyczne badania początku i wzrostu medycyny sq̨dowej, „Rocznik Wydziału Lekarskiego w Uniwersytecie Jagiellońskim" Kraków 1839, t. II, s. 166.

84 Полное собрание законов Российской империи, с 1649 года. t. 24. С 6 ноября 1796 по 1798, Санкт-Петербург 1830, s. 396. 
Книга устав морской: о всем что касаеця доброму управленію в бытности флота на моръ, Тпографи льла Господня I720 Апръля вь 13 Аснь, Санкт-Петербург 1765, s. $147-149$.

Полное Собрание Законов Российской Империи: Собрание первое: С 1649 по 12 декабря 1825 года, Т. II, Тип. 2-го Отд-ния Собств. Е.И.В. Канцелярии, Санкт-Петербург 1830, s. 10-750.

Соборное уложение 1649 года, Москва, Печатный двор, 29 января 1649, Печатный двор, 29 января 1649 [29.01.7157], s. 1-699.

\section{Literatura}

Becker E.M., Medicine, Law, and the State in Imperial Russia, Central European University Press, New York 2011.

Crosby B., Authentic Memoirs of the Life and Reign of Catherine II. Empress of all the Russias, collected from authentic MS'S, translations, \&c. of the King of Sweden, Right Hon. Lord Mountmorres, Lord Malmesbury, M. De Volney, and other indisputable authorities, printed for the author and fold by B. CROSBY No 4 Stationer's Courts Ludgate Street, London 1797.

Feigel L., Podręcznik medycyny sądowej, na podstawie dzieł E. Hofmanna, J. Maschki i własnego doświadczenia, Nakładem autora i związkowej drukarni, Hotel Żorża, Lwów 1883, s. 10.

Hechel F., Historyczno-krytyczne badania początku i wzrostu medycyny sądowej, „Rocznik Wydziału Lekarskiego w Uniwersytecie Jagiellońskim”, Tłocznia Stanisława Gieszkowskiego, Kraków 1839, t. II.

Helcel A.Z., Rys postępów prawodawstwa karnego ze szczególnym uwzględnieniem na nowsze w tej mierze usiłowania, Drukarnia Kwartalnika Naukowego, Kraków 1837.

Kalachov N., Iuridicheskiǔ viestnik 1863, No. 1, University of Chicago, s. 7-11.

Koritké J.G., Archives d'anatomie, d'histologie et d'embryologie normales et experimentales, t. 60, Editions Alsatia, Leningradskoe 1971.

Rakowiecki I.B., Prawda ruska: czyli prawa wielkiego xieccia Jarowslawa Wladymirowicza... Rys historyczny zwyczaiów, obyczaiów, religiy, praw y języka dawnych slowiańskich y slowiańsko-ruskich narodow, t. 1, Drukarnia XX. Piiarów, Warszawa 1820.

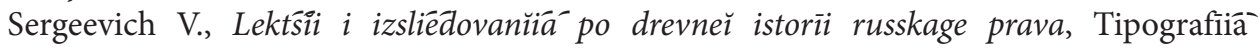
A. Transheliā, Sankt-Petersburg 1903.

Sołodov D.A., Reformy procesu karnego w Rosji: zarys historyczno-prawny, Społeczne Stowarzyszenie Prasoznawcze Stopka, Łomża 2015.

Sygit B., Historia prawa kryminalnego, Zapolex Media, Toruń 2007.

Tokhomirov M.N., A Manual for the Study of the Russian Truth, Publishing House of the Moscow University, Moscow 1953.

Акопов В., Судебная медииина 3-е изд., пер. и доп. Учебник для бакалавров, Издательство Юрайт, Москва 2015.

Амплеева Т.Ю., История уголовного судопроизводства России, Моск. гос. ин-т междунар. отношений (ун-т) МИД России, Москва 2009. 
Архангельский Г.В., История неврологии от истоков до ХХ века, Медицина, Москва 1965.

Баженов Н.Н., История Московского Доллгауза, ныне Московской городской Преображенской больницы для душевнобольных, Моск. гор. обществ. Упр, Москва 1909.

Белевитин А.Б., Немченко В.И., Обуховская больница, VMA, Санкт-Петербург 2003. Ведров С.В., О денежных пенях по Русской Правдю: сравнительно с законами Салических Франков, Въ Университетской тииогуафіи (М. Ндткоиъ), Москва 1877.

Верекундов В., Историческій очерк Кафедры диагностики и общей терапіи в Императорской военно-медииинской академіи (Кабедры общей патологіи, общей терапіи и врачебной діагностики в Императорской медико-хирургической академіи): матеріалы для исторіи медицины в Россіи, Тип. В. Киршбаума, СанктПетербург 1898.

Верне И.И., О времени и причинах образования московских приказов, Университетская типография, Москва 1907-1908.

Веселаго Ф., Краткие сведения о русских морских сражениях за два столетия с 1656 nо 1856 год, Тип. Императорской Академии Наук, Санкт-Петербург 1871.

Гнилорыбов П., Зырянов В., Томчин М., Россия в эпоху Петра Великого. Путеводитель путешественника во времени, Эксмо-Пресс, Москва 2017.

Гриненко А.В., Костанов Ю.А., Невский С.А., Потапов В.Д., Об адвокатской деятельности и адвокатуре в Российской Федерации. Научно-практический комментарий. Учебное пособие, Издательство Проспект, Москва 2019.

Громбах C.M., Русская медицинская литература XVIII века, Изд-во Академии мед. наук СССР 1953.

Доливо-Добровольский А.В., Харламова N.О., Санкт-Петербург. Хроника трех столетий, Санкт-Петербург 2003.

Дулов А.В., Судебная медицина и Петербургская академия наук, Судебно-медицинская экспертиза 1962, $\mathrm{Nr} 2$, s. 299-316.

Иванович Смолярчук В., Адвокат Феодор Плевако: Очерк о жизни и судебной деятельности адвоката Ф.Н. Плевако, Юж.-Урал. кн. Изд-во 1989.

Ионасович Левинштейн И., История фармации и организация фбармацевтического дела, Наркомздрав СССР, Гос. изд-во мед, Москва-Ленинград 1939.

Каменский А.Б., Om Петра I до Павла I. Реформы в России XVIII века. Опьт иелостного анализа, Российский государственный гуманитарньй университет, РГГУ, Москва 2001.

Кащенко П.П., Ближайшие задачи в деле попечения о душевнобольных, „Современная психиатрия" 1911, s. 485-513.

Клевно В.А., Кононов Е.В., История судебной медицины в России в Х-начале ХХ века, Москва 2018.

Князев Е., История России. Вторая половина ХІХ - начало ХХ века 2-е изд., испр. и доп. Учебник для академического бакалавриата, Издательство Юрайт, Москва 2019.

Коллманн Н.Ш., Преступление и наказание в России раннего Нового времени, Новое литературное обозрение, Москва 2017.

Кузьмич Кондратьев И., Спдая старіна Москвы: историческій обзор и полный указатель ея достопамятностей: соборов, монастырей, иерквей, стпн, двориов, памятников, общественных зданій, мостов, площадей, улии, слобод, урочищ, 
кладбиш, и проч. и проч.: с подробным историческим описаніем основанія Москвы и очерком ея зампчательных окрестностей, Изданіе книгопродавца и а морозова, Москва 1893.

Мирский М., Медищина России XVI-XIX веков, Российская политическая энциклопедия, Москва 1996.

Митрофанович Лукьянов П., История химических промыслов и химической промыштенности России до конца ХІХ века: Общие вопросы истории химической промьшленности, Изд-во Академии наук СССР, Москва 1948.

Михайлович Раскин Н., Химическая лаборатория М.Б. Ломоносова: химия в Петербургской Академии наук во 2-й половине XVIII в, зд-во Академии наук СССР [Ленинградское отд-ние], 1962.

Неволин К.А., Изсльдованія о различных предметах законовюдюнія, Тип. Эдуарда Праца, Санкт-Петербург 1859.

Нечаев А.А., Очерки по истории Обуховской больницы, Под ред. С.И. Вольфковича, Москва 1952, s. 3-618.

Николаевич Бубенников А., История земли Можайской Руси Святой: 512 г. до н.э.-1812 г, Парад, Можайск, Парад 2003.

Панько Н.К., Присяжные поверенные и адвокать: история развития, сравнительный анализ их правового статуса и полномочий по уставу уголовного судопроизводства 1864 года и законодательству российской федераци, Судебная власть и уголовный процесс, Nr 3, Роскомнадзора Москва 2014, s. 243-251.

Пашков К.А., Ромодановский П.О., Пашинян Г.А., Судебная стоматология - страницы истории, Эслан, Москва 2009.

Петрович Лей А., Энииклопедический медииинский лексикон: Часть третья, тип. А. Иогансона, Петербург 1844.

Попов А.Н., Русская правда в отношении к уголовному праву, Унив. Тип, Москва 1841. Прозоровский В.И., Судебная медицина, Юридическая литература, Москва 1968.

Решетун А., Вскрытие покажет: Записки увлеченного судмедэксперта, Альпина Паблишер Москва 2017.

Сербский В., Приговор. Об экспертизе душевнобольных и преступников, Алгоритм, Москва 2019.

Сергеевич В.И., Лекиии и исследования по древней истории русского права, Тип. М.М. Стасюлевича, Санкт-Петербург 1910.

Смирнов Д., Нижегородская старина: Нижегородские были, Изд-во, Нижегородская ярмарка, Нижний Новгород 1995.

Стецовский Ю.И., Становление адвокатуры в России, Wolters Kluwer Russia, Москва 2010.

Сухих И.Н., Лихачева Д.С., Петр Великий в русской литературе: воспоминания, оценки, образ, Геликон Плюс, Санкт-Петербург 2009.

Таксами Ч.М., Константиновна Шафрановская Т., Владимировна Иванова Е., Приглашаем в Кунсткамеру, Б/и, Санкт-Петербург 2001.

Тихомиров М.Н., Епифанов П.П., Соборное уложение 1649 года, Изд-во МГУ, Москва 1961.

Тихомиров М.Н., Пособие для изучения Русской Правды, Издательство Московского Университета, Москва 1953. 
Филиппович Крылов И., Судебная экспертиза в уголовном проиессе, Leningrad State University, Ленинград 1963.

Хохлов В., Судебная медицина. Руководство в 3 m. Том 1 4-е изд., пер. и доп. Практическое пособие, Издательство Юрайт, Москва 2019.

Черепнин Л.В., Юшков С.В., Памятники русского права, t. 4, Госюриздат, 1957.

Чистович Я.А., История медицинких школ в России, Тип. Якова Трея, Санкт-Петербург 1883.

Юрьевич Андреев А., Московский университет в общественной и культурной жизни России начала ХІХ века, Языки рус. Культуры, Москва 2000. 